\title{
Contributions of Sasi to Sustainable Living of Saparua Indigenous Community, Indonesia
}

\author{
Jenny Koce Matitaputty, Helius Syamsuddin and Enok \\ Maryani \\ Faculty of Social Science Education \\ Universitas Pendidikan Indonesia \\ Bandung, Indonesia \\ jn_stuard33@yahoo.com
}

\author{
Mohammad Ali \\ Faculty of Technology and Vocational Education \\ Universitas Pendidikan Indonesia \\ Bandung, Indonesia
}

\begin{abstract}
This study is aimed to find out the problems on how Sasi supports sustainable living in Saparua indigenous community, consisting of fifteen villages spread into two sub districts, i.e. Saparua and East Saparua. This research uses ethnographic approach. Data were taken using observation, interview, and triangulation techniques. According to Sasi's types and categories spread, the result shows that Sasi has decreased and even disappeared for more than $\mathbf{7 5 \%}$ in Saparua despite the effort to revitalize. This is in contrary to Sasi's contribution in natural resource management to support the sustainable living of Saparua community from the perspectives of economy, society, and ecology portrayed in sustainability pillars, which are economy and society as being constrained by environmental limits. Hence, Sasi's cultural preservation can be the exact way for the ongoing living.
\end{abstract}

\section{Keywords-Sasi; sustainable living}

\section{INTRODUCTION}

People nowadays want something instant; they tend to exploit natural resources and forget the long-term aspects that are far more beneficial for them [1]. Deforestation and coral reef destruction in several places including Indonesia, specifically in Moluccas have become a concern for either the government or the society to not only know, but also consider. Data show that deforestation in both Java and Borneo reaching 1.8 hectares every year has caused $21 \%$ of 133 million hectares of Indonesian forests to disappear. This dematerialization of the forests brings about environmental damage, increasing natural disasters, and flora and fauna extinction threat [2]. In the last half century, coral reef degradation has increased from $10 \%$ to $50 \%$ [3]. Some of the causes of coral reef damage are development in the coastal area, waste disposal from both land and sea activities, sedimentation caused by river damage, destructive fishing using cyanide and prohibited tools, and coral reef mining [4]. Natural resources will be gone if there is no natural and sustainable management.

The increasing number of environmental degradations in many developing countries is often related to rapid economic growth and the loss of traditional knowledge system and traditional resource management organization [5]. Local knowledge has a voice in the development and conservation discourse in managing resources sustainably in order to obtain the global purpose. Sustainable natural resource management in this era therefore becomes an important matter to improve. The only solution that can be executed is ongoing solution [6].

Local knowledge of Sasi culture in Moluccas is basically interpreted as an effort to preserve etiquette in living in the society. Natural cash crop which is limited to certain period of time is aimed to maintain the balance in nature and another ecosystem. This results in preserved natural resources, in order to support the lives of the society within.

Sasi application is based on the principle of sustainability and balance of the human relationship with the natural (ecosystems) between man and nature are inseparable. Nature is an integral part of human beings. Destruction of nature means also the destruction of the human and indigenous people [7].

Sasi is in line with sustainability is the dream of living well; sustainability is a dynamic balance with others and the environment, it is the harmony [8]. However, Sasi culture in certain areas of Moluccas has degraded. This is supported by findings from a previous study, which states that in some villages of Maluku Sasi was still functioning, in others it was growing weaker or had disappeared entirely [9].

The image of Sasi in the society in Moluccas becomes a part of Sasi's existence in Saparua Island. There are many deforestations, blasting fishing which results in coral reef damage. Ihamahu's area is regulated under Sasi but not actively policed and, therefore, extensively damaged by blast fishing [5]. This phenomenon interests researchers to conduct a study on Sasi in Saparua indigenous community.

Local wisdoms have universal values despite being 'local' [1]. Sasi will be able to create something local yet global if supported by the role of community in managing natural resources available in Saparua indigenous community because they are potential to be the basic of sustainability. This study seeks to see the existence of Sasi in Saparua today and how Sasi contributes to maintain the sustainable living of Saparua indigenous community. 


\section{LITERATURE REVIEW}

Local wisdom is basic knowledge gained from living in balance with nature. It is related to culture in the community which is accumulated and passed on [10]. Local wisdom means harmonious relationship between man, nature and the built environment in an area that is also influenced by its culture [11]. Indigenous knowledge is local knowledge unique to a given culture or society [12]. It is the systematic body of knowledge acquired by local people through the accumulation of experiences, informal experiments, and an intimate understanding of the environment in each culture. This indigenous knowledge has been modified through accumulated practical experiences and passed on from one generation to the next.

In Maluku Province, Indonesia, natural resources are managed under a locally defined set of rules and regulations known as sasi [13]. Sasi was, therefore, resuscitated as community-based management, as 'environmental wisdom' applied to sustainability problems [14]. Sasi is a customary resource management system in the eastern part of Indonesia, encompassing spatial and temporal prohibitions on harvesting crops, cutting wood, and gathering other products from the forest, tidal zone, or marine territory of a village [15].

The management of natural resources is one of important thing that needs to be discuss to increase the development to continue our generations. With a lot of potential that we have we can build the development of our nation with no worries and afraid of life sustainable. But the fact is too much of exploitation causes disaster for us. Because of the management that work without think of the environment. That's why sasi role is needed to take control and to keep the natural resources growing up. In another word, vegetative and biologic natural resources need to be everlasting keep in one period to recovers the growth to get the satisfy result [16]. This is related to Sustainable living [17]. Sustainable living is defined as "lifestyle that aims to reduce the use of natural resources. Sustainable living is a lifestyle that attempts to reduce an individual's or society's use of the Earth's natural resources and personal resources [18]. Sustainable living is an ongoing learning process based on our individual definitions of quality of life. It's about making decisions that make sense to us, given our needs and values. It's about living with intention. It's about being fully aware of the consequences of our decisions, both positive and negative [19].

One of continue life conception that revealed the meaning of triple-bottom-line, to fulfill the ecology, social, and economy needs. Three sustainable pillars, which is: Thus, sustainability has been illustrated as having three overlapping dimensions: the simultaneous pursuit of economic prosperity, environmental quality, and social equity, also known as the "three pillars" of sustainability. Sustainability triangle conveniently reminds us of the three factors environmental, economic, and social. For our personal decision-making, it works the best. Keep in mind another image, one that is more accurate from a biological perspective. In this "nested model" scenario, our economy is a small part of our society, and our society is a small part of our environment [19]. We hope that this study will benefit other communities and individuals. We wish our efforts to serve as a guideline for the practice of collecting local wisdom related to the environment and for natural resource protection that contributes to developing a world that is sustainable through the next generation [20].

\section{CASE STUDY AREAS}

This research was conducted in Saparua island, which consists of two sub districts: 1) Saparua, which area covers 79.90 square kilometers and consists of seven villages, they are Porto, Haria, Paperu, Booi, Saparua, Tiouw and Kulur; and 2) East Saparua, which covers an area of 96.60 square kilometers and has eight villages, they are Siri-Sori Amalatu, Tuhaha, Ihamahu, Nolloth, Itawaka, Ouw, Siri-sori, Ulath and Mahu.

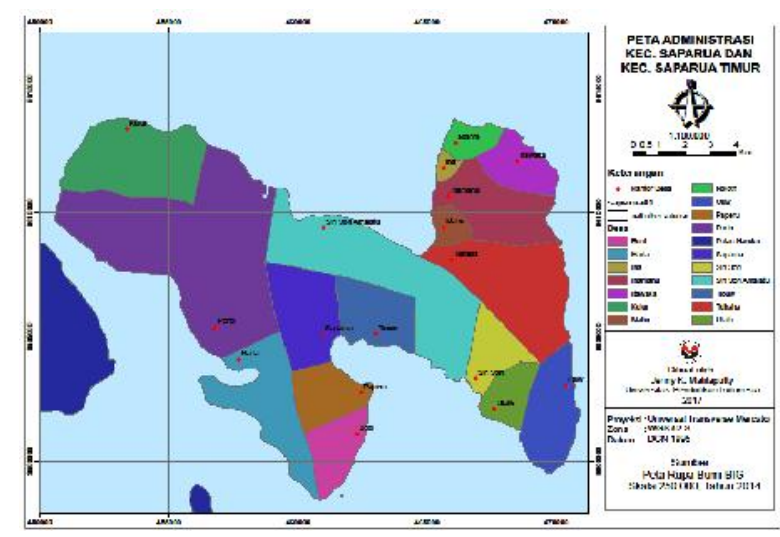

Fig. 1. Map of Saparua Island.

\section{METHODOLOGY}

This study uses ethnographic research method to describe, analyse, and interpret the culture of one community/tribe/nation. Ethnographic research is a Qualitative design for describing, analyzing and interpreting the patterns of a culture-sharing group. Culture is a broad term used to encompass all human behavior and beliefs. Typically, it includes study of language, rituals, structures, life stages, interactions and communication [21]. Therefore, the researchers are the key instruments.

Informants were chosen based on their familiarities on the information related to problem's identifications. Hence, the most important informant was Raja, the leader of the villages; the next informants were secretaries of the villages who provided the village data, the Head of Governmental Affairs who dealt with governmental matters, Kewang, Pakter and former Bas (for Noloth) who were executors of Sasi ritual (Pasawali) so that it eased researchers in obtaining data related to the research. The research was conducted for three months, from May to July 2017.

Data collecting techniques in this research are observations and interviews. Observations are chosen to let researchers see things not discussed in interviews. Researchers gave informants freedom in answering questions to strengthen the data obtained from the observations. Afterwards, Triangulation was done to validate one data source with other data sources [22]. Triangulation played an important 
role because there would not be acceptable information without triangulation.

\section{FIndINGS AND DisCUSSION}

\section{A. Mapping of Sasi Categories (Status)}

Sasi is a management of natural products that are limited within a certain time to maintain the balance of nature and other ecosystems for sustainability, natural resource maintenance, as well as a support to the continuity of life of the community. For Saparuan people, Sasi is a customary rule that must be obeyed together to maintain the potential of natural resources through customary ritual (pasawali) which begins with 1) Sasi marking preparation: (a) Big Sasi markings in the shape of cora-cora replica consisting of gadeng wrapped with coconut leaves and sentap; (b) small Sasi markings from only one pole, wrapped with coconun leaves; 2) close Sasi, which is a prohibition to take natural resources for a period of time; 3 ) open Sasi, which is a permission to take natural resources.
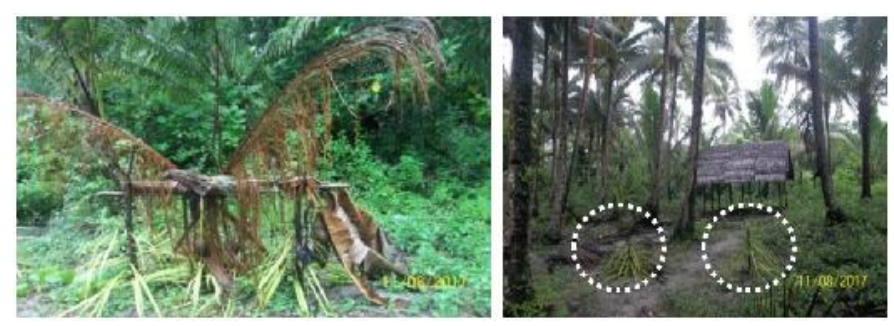

Fig. 2. Big Sasi markings in the shape of cora-cora replica and small Sasi markings.

Saparua community knows different kinds of Sasi. First, Sasi for public welfare: a) Land Sasi: Some kinds of trees such as sago (sagu), nutmeg (pala)), clove (cengkeh), jackfruit (cempedak), areca nut (pinang), banana, palm blossom (mayang), coconut etc. This has rules for the protection of several types of natural resources such as pineapple, walnuts, Cempedak, durian, areca nut, nutmeg, and sago leaves [23]; b) Sea Sasi: sea cucumbers, lobster, lola snails, and fish. This Sasi area is actively guarded to protect the top shells (Trochus niloticus) and sea cucumbers (various species) [5]. Sands, sea cucumbers, lola, caping-caping, fish, mangrove trees, lompa fish, and other types of fish are available around the coastal area [24]; c) Individual Sasi, which in its development, is also known as Church Sasi (Sasi Gereja).

Second, Sasi as security to maintain the security of the village due to disputed trees. The tree will be dissolved until the decision of the winner by the court, if during the period of the dispute the tree produces fruit, managed by kewang and the result will be submitted to the winner of the case. Third, Sasi Babaliang: This type of Sasi is better known as auction Sasi in saparua and intended for the development of the village. Auction results are usually used for the purposes of village development (renovation of houses of worship, roads and other public facilities and infrastructure). Furthermore, the winning bidder shall have full rights to exploit the fishery resources which are disseminated in the designated area [25].

From the data obtained, the distribution of land and sea and the category (status) of Sasi in the life of Saparua indigenous people today can be analyzed as follows:

- The strong category, the sasi which is still carried out to date, is the land of Siri-Sori Amalatu, Porto, Ulath and Ihamahu (except sea Sasi).

- The weak category, because of the emptiness of the leader (king) of the land of Itawaka, Ouw, Siri-Sori, Paperu (currently in dispute with the foreign businessman from Switzerland who built Cape Paperu in the sea Sasi region) and the State of Haria because leaders who have lost authority.

- The revitalization category, because the policy of the newly inaugurated king, found in the land of Nolloth and Tuhaha.

- The lost category, because it has not been implemented for about 30-40 years, found in Kulur, Saparua, Tiouw, Booi and Ihamahu (sea Sasi).

Based on the data that has been presented, the authors make a calculation in the presentation of the existence of Saparua status in the table 1 below:

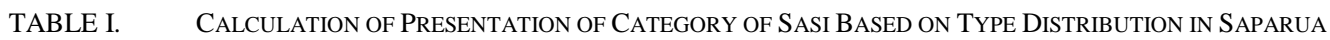

\begin{tabular}{|c|c|c|c|c|c|}
\hline \multirow[t]{2}{*}{ Category } & \multicolumn{3}{|c|}{ Kinds of Sasi for Welfare Improvement } & \multirow[t]{2}{*}{ Sasi as Security } & \multirow[t]{2}{*}{ Auction Sasi } \\
\hline & Land Sasi & Sea Sasi & Individual Sasi & & \\
\hline Strong & $\begin{array}{l}4 \text { villages } \\
25 \%\end{array}$ & $\begin{array}{l}3 \text { villages } \\
18,75 \%\end{array}$ & $\begin{array}{l}14 \text { villages with majority Christians } \\
\text { Church Sasi } 87,5 \%\end{array}$ & & $\begin{array}{l}1 \text { village } \\
6,25 \%\end{array}$ \\
\hline Weak & $\begin{array}{l}5 \text { villages } \\
31,25 \%\end{array}$ & $\begin{array}{l}5 \text { villages } \\
31,25 \%\end{array}$ & & $\begin{array}{l}1 \text { village } \\
6,25 \%\end{array}$ & $\begin{array}{l}3 \text { villages } \\
18,75 \%\end{array}$ \\
\hline Lost & $\begin{array}{l}5 \text { villages } \\
31,25 \%\end{array}$ & $\begin{array}{l}6 \text { villages } \\
37,5 \%\end{array}$ & & $93,75 \%$ & $68,75 \%$ \\
\hline \multirow[t]{2}{*}{ Revitalization } & $\begin{array}{l}2 \text { villages } \\
12,5 \%\end{array}$ & $\begin{array}{l}2 \text { villages } \\
12,5 \%\end{array}$ & & & $\begin{array}{l}1 \text { village } \\
6,25 \%\end{array}$ \\
\hline & & & $\begin{array}{l}2 \text { villages with majority Muslims } \\
12,5 \% \text { (not) }\end{array}$ & & \\
\hline Total & $100 \%$ & $100 \%$ & $100 \%$ & $100 \%$ & $100 \%$ \\
\hline
\end{tabular}


From the table above, the existence of Sasi currently in Saparua has decreased and even disappeared more than $75 \%$. Despite revitalization efforts in Nolloth and Tuhaha. Based on these findings the authors doubt the opinions of previous studies. Some form or remnant of Sasi is still extant in $75 \%$ of the villages of the islands of central Maluku [26]. However, it is in line that the current application of Sasi is beginning to disappear and almost disappears altogether [27].

Based on the findings of field data, the authors conclude that Sasi in a village is very dependent on the existence of a Village Leader (King). This can be seen in villages that still maintain the existence of Sasi but are weak in its implementation because of the absence of a leader (King), like in Siri-Sori, Ouw, Paperu and Itawaka villages. The authority of the king also influences the existence of Sasi, as encountered in the village of Haria; despite having a King and kewang but the village cannot implement Sasi for seven years. The King's wisdom can be found in the land of Tuhaha and Nolloth, the new (King) leaders seek revitalization. Researchers need to review the babaliang Sasi which gives freedom to auction winner to exploit natural products to prevent destruction and extinction of marine lives.

\section{B. Contributions of Sasi to Sustainable Living}

Basically, Sasi has the principle of sustainability and balance of human with another human relationships and man with nature relationships. Sustainable living is a lifestyle that attempts to reduce an individual's or society's use of the Earth's natural resources and personal resources [18]. One of the issues of achieving sustainable development is how to repair the environmental damages without sacrificing the economic development and social justice [28]. Thus, sustainability has been illustrated as having three overlapping dimensions: the simultaneous pursuit of economic prosperity, environmental quality, and social equity [29].

Hence, Sasi as a part of cultural institution in Moluccas, especially in Saparua indigenous community, should guarantee the utilization and management of biological and bio-natural resources for the environment; not only to ensure that food supplies are available, but also to understand the process of continuation of life of the plants, sea creatures, the cycle of growth of the earth (environment), and the continuation of human life as supporters (social and economic).

1) Environment perspective: A strong narrative of environmental degradation surrounds the study sites in some villages such as Ihamahu, Haria, Nolloth and Itawaka. From the description of Mr. Pit Hitipeuw (18 May, 2017), Ihamahu village has not implemented sea Sasi for a long time. This causes damage to coral reefs due to human greed using incompetent fishing tools so that it becomes increasingly difficult for fishermen to get fish. The same thing happens in Noloth village which has not implemented Sasi for about ten years due to coral damage from the use of compressors done by traders from
Madura. This is supported that in the past, they were harvested by Madurese compressor divers from Java [5].

Diminishing existence of Sasi affects the decrease of various types of marine life such as sea cucumbers, lola slugs, and fish. As formerly stated by Mr. Cia Pattileamonia (7 May 2017) that when Sasi was enforced in Haria, fish were easily found in the beach port, but now fish are very difficult to find because people use printer ink to catch squids, fish move away from the harbor and other sea creatures died from printer ink intoxication. Besides printer ink, people also use fish bombs such as the incident that just happened on 19 February 2017 to Welem Molle who lost his right hand when assembling a bomb for fishing.

Sasi that began to decline and even disappear in the villages in Saparua affects not only the sea area but also the forest area. Tiouw, Saparua and Kulur admit that unsustainable sasi causes many plant ecosystems to not go according to their cycles. This has brought about scarcity of coconut and sago trees in those three areas. Mr. Leo Manuputty, on 11 May 2017 interview, said that if Sasi is enforced, the community is obliged to replant the felled trees so that there is regeneration and prevention of extinction which resulted in many acts of theft by the community and forest destruction by illegal logging in Haria and Itawaka.

The destruction of forests and the scarcity of certain types of natural resource plants indicate that these areas must be re-protected by controlling humans in managing the selective use of natural resources through the culture of Sasi. This is because Sasi culture sasi organises humans to control themselves in taking natural results according to the needs and based on the rules of sustainability of natural resources by using environmentally friendly fishing tools (prohibition of using bombs or poison (bore) and redi etc.) as well as the scheduled time, just like what people in Porto, Ulath, Sirisori and Siri-Sori Amalatu villages do. With environmentally friendly equipment and awareness of the natural resource life cycle in both forests and oceans, environmental ecosystems will continue to be sustainable. This tradition is in addition intended to preserve the natural environment, as well as the form or manner of the Moluccas in maintaining the productivity of agricultural products and other marine [30].

Sustainability in an ecological or environmental perspective in Sasi culture teaches humans to live in harmony with nature, so that every creature can live by its cycles. If humans do not understand their life cycles then the marine life, as well as the trees will be reduced and extinct because they are unable to reproduce. Sasi as a safe guard to maintain the quality of population and natural resources. The prohibition of harvesting prematurely, there will be an increase in the population of natural resources [31].

Based on research data and opinions of experts, the first thing to do is socialization about natural products that have high economic value in terms of reproduction systems of lola slugs, sea cucumbers, and other natural resources to kewang, Saniri, kings as well as the community to prevent decrease or even extinction of marine creatures from happening. Next, review on sea Sasi rules which does not discuss about corals as a part of natural resources that avert the increase of sea 
water abrasion to the residential area and threatens the residence due to the use of fish bombs, printer ink and compressor.

Sasi thus aims as a remedy to restore the balance of damaged or disturbed nature. Because without this recovery, the consequences are diminishing and there is a threat of extinction from the existing natural resources as well as the threat of environmental damage that affects humans, and the threat of food shortage.

2) Economic perspective: Generally the main motivation behind Sasi is the availability of life insurance, with this guarantee, human beings must take responsibility for maintaining the nature of creating a better quality of life by improving the quality of natural resources.

Sasi can support the sustainable living of Saparua community economy. Mr. Ahmad Sanaky on 17 May 2017 interview stated that ripe nutmegs are shown by the split skin of the flesh and blackened seeds wrapped in red fuli. Such ripe nutmegs need 200 lasa/piece for $1 \mathrm{~kg}$ and are sold for Rp 110,000 . Nutmeg fuli 1,000 lasa/piece produces $1 \mathrm{~kg}$ dry flowers sold for Rp 150,000 and 10 fruit peels for Rp 10,000. If Sasi were not used and people harvested them when they are not ripe, they would need approximately 400 lasa/piece

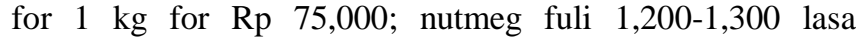
produces $1 \mathrm{~kg}$ dry flowers and 20 peels for Rp 10,000.

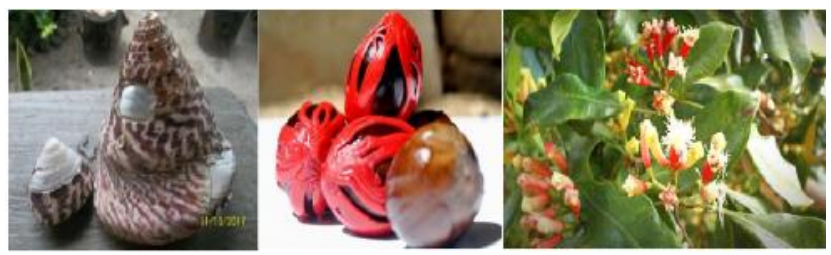

Fig. 3. Natural resources in the implementation of Sasi.

The clove that is cultivated using Sasi usually produces more fruits because it has been prepared before the trees produce the fruit by clearing the area around the forest so that the sunlight will provide maximum yield production. Supervision on the natural resource management by kewang affects the abundant clove products. If people harvested them after the cloves fell, the selling value would decrease. A good clove yield has a weight of 12 cups for $1 \mathrm{~kg}$ of dried

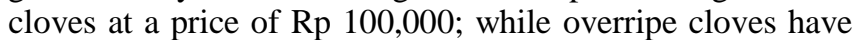
shrunk 24 cups for $1 \mathrm{~kg}$ are sold for Rp 75,000. In addition, if people harvest too late because of too many clove trees, cloves become pods (swollen and change color to red and even blackened) and do not have a selling price so that people experience losses.

Harvest time of one sago tree grown using Sasi will be controlled so that it can grow 40-50 sago herbs. The price of 1 sago herbs is currently Rp 100,000; thus Rp 40,000$5,000,000$ will be obtained. However, if not dissolved, a sago tree can only produce 25-30 sago herbs, which means the profit is only $\mathrm{Rp} 2,500,000-3,000,000$. Coconut fruits that can be processed into copra with sales of Rp 15,000 / $\mathrm{kg}$ or into brown sugar (Saparua sugar) for Rp 30,000 and has a high value than selling a coconut that is only valued $\mathrm{Rp}$ 5,000 .

The same thing goes for marine products. For sea cucumbers, the bigger the size, the bigger the capacity, approximately 6-10 sea cucumbers for Rp 600,000; whereas without Sasi, they will only be consumed by the community. If they are sold before reaching the exact size, there will only be 10-15 sea cucumbers $/ \mathrm{kg}$ with low selling price. Meanwhile, lola slugs will grow to $1 \mathrm{~kg}$ using Sasi, with $\mathrm{Rp}$ 12,000 selling price. If Sasi is not used in the breeding process, lola slugs will only cost Rp 10,000 for 20 slugs $/ \mathrm{kg}$ and the shells cannot be utilized.

From the data description, there is a prominent difference from the management of natural resources in the implementation of Sasi which has a very high selling price value to bring benefits to the community. Thus, the authors argue that Sasi gives a great contribution for every supporter in helping the economic sustainability of society, especially Saparua community. The selling price of natural resources utilized using Sasi can be high because not only are the products abundant to harvest, but the quality of the products is also good because they are harvested after they are ripe. This is also supported by the statement which says that implementation of the Sasi that is not taken up by the time the results can be harvested up to the quality of the results of the earth and the sea, so that it can economically productive [23].

Therefore, Sasi needs to be re-functioned because Sasi is the management of quality achievement of natural and biological resources product of quality and economic value. The authors believe that the training of small and medium business development to the community of Saparua in handicraft creative industry management of raw materials from natural resources such as the utilization of lola snail skins as a source of income needs to be done. It is intended that the lola snail shells are not thrown away or sold in the form of raw materials to the middlemen, but can be utilized for higher economic value. Similarly, training for women to manage the nutmeg skin for a fresh drink that has a high economic value, clove oil distillation, jackfruit into chips and so forth. A variety of natural resources resulting from Sasi products can be used to become a source of income so that the benefits of Sasi are parts of the creative economic sustainability of the Saparua community.

3) Social perspective: Social sustainability arises when people believe that as human beings, they always live in need of one another, creating a variety of values of mutual respect, help, and high kinship so as to create a society that lives orderly and peacefully. The portrayal of this relationship can be found through interviews with $\mathrm{Mr}$. Ahmad Sanaky (12 July 2017) that when the cloves ripe, strong relationships between individuals and families is usually depicted, because if there are families who have many trees then the group of those families will use the cloves. Part of a traditional sago exchange system, in this case maano, in which labour is offered in exchange for a share of the harvest, and Maano may operate either between 
villages or within a village [32]. From the social point of view, the Sasi affects the relationship between individuals and clans as it strengthens [33]. This social sustainability can be found through the Ma'ano culture, i.e. helping each other or helping to harvest the results of natural resources. Communal ownership is defined as a shared ownership, causing the right and duty to manage, maintain and preserve it together as a form of existence of indigenous fellowship. In the context of ownership, resource and marine areas considered to be owned collectively, not individually [34].

Sasi in a communal practice requires all members of the society to be responsible for maintaining natural resources. This sense of togetherness certainly creates harmony in the society so that villages that implement Sasi will look wellordered, well-organized, and clean. Signs of sasi also mean a harmony in neighboring villages to respect the village implementing sasi. This is in line with a statement that says indicators of social sustainability in Sasi were measured is community harmony. Community harmony present and future community harmony was significantly greater in Sasi villages [30].

The shared responsibility of maintaining order and security of natural resources through the culture of sasi makes reluctance to steal other people's property, because there are sanctions such as physical sanctions, social sanctions, and public belief in the power of ancestral spirits. This is what makes people afraid to violate the rules of sasi. The form of social sanction also makes the deterrent effect of having to endure lifelong shame. As the development progresses, the form of physical sanctions begins to be abandoned and transfers to the form of sanctions in the form of fines (money) as a form of compensation for the stolen goods. Violation of the sasi system will cause fine for the violators which can be a sum of money [5].

Another social sustainability is that when Sasi opens, everyone harvesting the natural resources will give some of the harvest to the farm. In Siri-sori, for example, if there are 1000 lasa/nutmeg, then 100 pieces will be given to kewang, if there are 10 coconuts, then 1 piece is given to kewang. This illustrates that $1 / 10$ part of the harvest is given to kewang. Kewang then keeps the given harvested products to be shared equally into three parts with the king, mosque/church, and kewang. This distribution demonstrates three stone stoves in Saparua indigenous community. In Moluccas must make good relationship with the "tiga batu tungku" (three-stone stove). The "tiga batu tungku" (threestone stove) or three leaders of religion, tradition and government regulate and influent the norms in society [35]. There is a value of social justice, appreciation, and a form of gratitude to the leaders of the country, kewang as the executor of Sasi and the mosque or church that support the implementation of Sasi.

Hence, Sasi can be regarded as a controlling tool in the utilization of natural resources that creates social relations, family values, respect, security (conflict resolution), solidarity and harmony. Therefore, good communication among all parties is necessary to withstand Sasi to support the sustainable living of Saparua indigenous community.

\section{CONCLUSION}

The existence of Sasi in Saparua is currently very apprehensive because there are four villages that have lost Sasi. There is a village with Sasi that is weakened because of the emptiness of the leader (king) as the main responsible party for the implementation of sasi. In addition, the king's authority has an influence on the sustainability of Sasi, as encountered in the village of Haria; although the village has a king and kewang, sasi has not been implemented for seven years. An image of the authority of the king who realizes the importance of Sasi can be found in Nolloth and Tuhaha villages for a revitalization effort.

The destruction of forests, the depletion of tree species, polluted even the destruction of marine lives resulting in the difficulty of fishermen looking for fish and reduced production of sea cucumbers and lola snails in some villages in Saparua, especially in Nolloth, Ihamahu (sea sasi), and Haria, is a big impact from a lack of implementation of Sasi in those villages. Therefore, the authority of a leader (king) in viewing the sustainability of Sasi must be accompanied by the spatial intelligence in making every village policy (regulation of the village) for the management of natural resources so that the culture of sasi remains a part in the life of Saparua indigenous community.

Sasi is not a rule that binds society in the narrow sense, but in the broad sense, that Sasi has sustainability values, Sasi has a big role because Sasi contributes in supporting natural resource sustainability so that human life sustainability is guaranteed. This is embodied in the pillars of sustainability, namely economic sustainable living, with the increasing quantity and quality of natural resources, the community has a greater advantage. Social sustainable living, with high solidarity, ma'ano (helping each other), and mutual respect can strengthen the good relationship between individuals, groups and with neighboring villages to create a harmonious life. The equally important part is on environmental sustainability, that the implementation of Sasi teaches humans to live in harmony with nature. Therefore, Sasi is a local knowledge of Saparua indigenous community that must be maintained for the sake of our generation.

\section{REFERENCES}

[1] D. Affandi and P. Wulandari, "An Exploration Local Wisdom Priority in Public Of Local Government Case Study in East Java", J. Eco. Res.,35, 61-76, 2012.

[2] E. Lisdiyono, The Economic Value Of Nature and the principle of local wisdom as environmental protection effort in Indonesia. Business, Economics and Law, 7, pp 25-32, 2015.

[3] L. Burke, E. Selig and M. Spalding, Reefs at Risk in Southeast Asia. World Resources Institute, 1-76, 2002.

[4] A. Solihin, E. Batungbacal and A. Nasution, Laut Indonesia dalam Krisis. Jakarta: Greenpeace Southeast Asia., 1-12, 2013.

[5] I. Novaczek, I. Herkes, J. Sopacua and M. Tatuhey, An institutional analyzis of Sasi laut in Maluku, Indonesia. Canada, Ottawa, Malaysia. Danida, IDRC Canada, ICLARM the World Fish center, pp 1-343, 2001.

[6] A. Satria, Penguatan Kapasitas Masyarakat Desa Dalam Akses dan Kontrol Terhadap Sumber Daya Alam. seminar dan Lokakarya menuju Desa 2030. IPB.Bogor, 2007.

[7] F. Capra, The Web Of Life, Yogyakarta: Pustaka Pelajar, 2002. 
[8] S. Nirahua and K. Kuahaty, "Authority of the Village in Maluku as Indigenous People in the Management of Natural Resources in the Sea Customary Rights", Scientific and Research Publications, 6,246$255,2016$.

[9] M. Gadotti, "Education for Sustainability: A Critical Contribution to the Decade of Education for Sustainable Development", Ecopedagogy, 4, pp 15-64, 2008

[10] M. Mungmachon, "Knowledge and Local Wisdom: Community Treasure", International Journal of Humanities and Social Science. 2(13) pp 174-181, 2012

[11] D. Dahliani, I. Soemarno and P. Setijanti, "Local Wisdom in built environment in globalization era", International Journal of Education and Research. 3(6) pp 157-166, 2015.

[12] R. Ellen, P. Parkes and B. Bicker, Indigeneous Environmental Knowledge and Its Transformations, Singapore: Harwood Academic Publishers, 2005.

[13] I Harkes, An Institusional analysus of sasi laut, a fisheries management system in Indonesia, Proceedings of the International Workshop on Fisheries Co-management, 2001.

[14] R. Ellen, "Nuaulu ritual regulation of resources, Sasi and forest conservation in eastern Indonesia", Journal South East Asia Research, 24( 1), pp 5-22, 2016.

[15] I. Harkes and I. Novaczek, "Presence, performance, and institutional resilience of Sasi, a traditional management institution in Central Maluku, Indonesia" Jurnal Ocean \& Coastal Management 45(4-5) pp 237-260, 2002.

[16] W. Pattinama and M. Pattipelohy, Upacara sasi Lompa di Negeri Haruku. Kementrian Pariwisata: Balai kajian Sejarah dan Nilai Tradisional, 2003

[17] E. Cubukcu, Walking for Sustainabe Living. Cultural Sustainability in the Built and Natural Environmen. Procedia ASEAN Conference on Environment-Behaviour Studies Hanoi Architectural University. Elsevier. Hanoi, Vietnam. Procedia Social behavoiur science. 33-42, 2013.

[18] J. Ainoa, A. Kaskela, L. Lahti, N. Saarikoski, A. Sivunen, J. Storgårds and $\mathrm{H}$. Zhang, Future of Living, In Neuvo, Y., \& Ylönen, S. (eds.), Bit Bang - Rays to the Future. Helsinki University of Technology (TKK), MIDE, Helsinki University Print, Helsinki, Finland, pp 174-204, 2009.

[19] M. Apel, C. Elliot, E. Glenn, J. Prichard, D. Rashash, D. Simon and V.S. Brouwn, Sustainable Living Handbook: A Citizen's Guide to Thoughtful Action. College of Forestry Oregon State University Corvallis : Oregon state University, 2011.

[20] W. Chaipar, T.P. Na Sakolnakorn and A. Naipinit, "Local Wisdom in the Environmental of a community: Analyaia of local knowledge in tha pong Village, Thailand", Journal of Sustainable Development, 8, pp 16-25, 2013.
[21] J.W. Creswell, Qualitative inquiri and research design ; chosin among five tradisions. London, United Kingdom; Sage Publucation, 2000.

[22] M. Ali, Memahami Riset Perilaku dan Sosial, Jakarta: Penerbit Bum Aksara, 2014.

[23] X. Xiuping, E. Kissya and Y. Yanes, Indigenous Knowledge and Customary Law in Natural Resource Management: Experiences in Yunnan, China and Haruku, Indonesia. Thailand : Asia Indigenous Peoples Pact (AIPP) Foundation, 2010.

[24] V.J. Pical, "The Impact of the Changes of Village Government Systems on Fishery Resources Community Base Managements in Moluccas Villages", Ichthyos, 7, pp 71-78, 2008.

[25] H. Latuconsina, "The Existence of "Sasi Laut" in Managemen Sustainable Fisheries as Local Community Based in Molucas", Triton, 5, pp 63-71, 2009.

[26] I. Novaczek, "Culturally Based Ethics And Resource Conservation: Learning From Small Islands", Culturally Based Ethics 1, pp 42-49, 2008.

[27] P.T. Berhitu, S. Hutabarat, S. Suprihayono and D. Suprapto, "Multi Dimension Scale Analysis Approach to Evaluate Sustainability in the Management of Ambon City Coastal Area", Journal of Oceanography and Marine Research. 4, pp 1-12, 2016.

[28] M. Ali, Sustainability Education Curriculum Development. Bandung: Upi Press, 2017.

[29] L. Liu, "Living within One's Own Ecological Means", Sustainability, 1, pp 1412-1443, 2009.

[30] A. Lonthoir, A.R. Asba, H.M. Tang and S. Hamdat, Concept "Larvu Ngabal" Settings in Marine Resource Management in Southeast Maluku Kei Islands. Scientific and Research Publications, 6, pp 524 $553,2016$.

[31] T. Iramayani, M. Amin, E.N. Ginting, Policy Model of Lake Toba Preservation by Parmalim Community. Management Science and Business Administration. 3, pp 32-37, 2017

[32] Y. Nathan, A. Uneputty, Y.A. Lewerissa and J.A. Pattikawa, Species aand Size Composition of sea cucumber in coastal waters of UN bay, southeast Maluku, Indonesia. Fisheries and Aquatic Studies. 3, pp 251-256, 2015

[33] H. Soselisa, A Comparison of Traditional and Innovative Subsistence Strategies on Buano during Periods of Socioenvironmental Stress, 1980-2003. In Modern Crises and Traditional Strategies: Local Ecological Knowledge in Island Souteast Asian, pp 143-165, 2007.

[34] R.H. Nendissa, "Eksistensi Lembaga Adat Dalam Pelaksanaan Hukum Sasi di Maluku”, Jurnal Sasi, 16, pp 1-6, 2010.

[35] M. Ganiamalia and M. Hamsah, "Formulating Business Strategy For A Social Business Company; Maximizing Maluku's Big Potential Of Seaweed", The Indonesian Journal Of Business Administration, 1, 415-422, 2012. 